others are more or less coarsely crystalline rocks, in which pyroxenic minerals usually predominate. These rocks are protruded in larger or smaller masses, and allied to them are dykes of a maculated basic rock, one of the hybrid rocks of Durocher. These dyke rocks are very undecided in composition, and in places may be classed as dolerite, while in others they must be called either Felstone or Trachyte. These maculated rocks seem to graduate into Dolerite and Augite, similar to and probably of the same age as the Tertiary dolerites of the Co. Antrim. A typical elvanoid rock belonging to oue of these groups (fourth or fifth) occurs at Goragh Wood (where it is extensively worked), coming up as a mass through the older Newry granite. This rock would answer the description for Nevadite, and possibly may be one of the granitic rocks belonging to the trachytes of Antrim. The rocks in the country about Carlingford Lough at present are only partially known; this, however, ought not to be for long, as they have been carefully examined by Mr. Traill.

In conclusion, I may mention that in the Mourne district to the north of the Lough, Mr. Traill found some of the dykes similar to and probably of the same age as the maculated dykes of the Carlingford district, that at their margins suddenly changed into a vitrioid rock, locally called Bottleite, that when examined by our colleague, F. Rutley, F.G.S., was pronounced to be Trachalite. This trachalite in places assumes a fibrous structure, apparently somewhat similar to that described in the obsidian of Ponza by Judd, and from fibrous it seems in places to pass into a minute columnar structure, the rock at the same time changing into anamesite or basalt. Judd seems to be of opinion that this fibrous structure is due to extreme pressure; with this I cannot agree, as it may occur in places where the dykes evidently occur filling shrinkage fissures. Many, indeed most, fibrous varieties of minerals and rocks, seem to be due to crystalline structure, the substance being deposited from solution; this, however, is not always the case, as in some instances the process seems to have been somewhat similar to drawing out heated glass into hairs. Such, however, could scarcely be due to pressure, and in many places where observed it looks as if the foundations of the dyke had given way, and that films between the consolidated portion of the dykes, or one of its walls, had been drawn out while the dyke was sinking.

WexroRD.

G. H. Kinahan.

\title{
GLACIAL EROSION.
}

Sir,-There are some points in Mr. Goodchild's interesting communications on Glacial Erosion (GEor. MAG. pp. 323, 356), concerning which I should like to make a few remarks. As I have not the advantage of much knowledge of the principal district which he describes, I cannot attempt to discuss them in detail, but as most points in his description appear to me to be common to all similar districts that I have seen, I venture to offer two or three general criticisms.

$\mathrm{He}$ objects (p. 328) to the theory which attributes the formation of rock ledges mainly to fluviatile action, because of (1) their height 
above the present level of the existing streams; (2) the general parallelism of the scars on opposite sides of the valleys; (3) the persistence of the peculiarities in form due to the nature of the bed. But with regard to these objections, I may remark that, so far as my memory serves me, they would hold in every hilly district that I have seen, where bedded rocks of a similar character exist, whether the district has been exposed to glacial action or not; also that it is no uncommon thing to see a river valley, with nearly flat bed, far wider than the existing stream. In some cases these may be explained by the volume of the stream being formerly greater, as it no doubt was occasionally in past history; in others the slow motion of the river from one side of the valley to the other would suffice. Further, that if a configuration were once given to the banks of the valley, and these were afterwards cut back in tolerably homogeneous rock by aerial denudation only, the original form would still be generally preserved, because the recession would be approximately uniform throughout. These phenomena are to be seen in the valleys of the Alps and the Jura, and if he is prepared to attribute these mainly to glacial eresion, he must get over some objections to which I will presently refer.

Is it necessary that swallow-holes should be formed by streams? Of course streams may form them-witness Gaping Gill; but I have seen districts riddled by swallow-holes, as the "Stony Seas" of the Eastern Alps, which were evidently formed by the rain drainage of a very small area. Some of those also in the Chalk have, I think, been simply dissolved out by the subterranean drainage of a very limited basin. The formation of a swallow-hole, I think, mainly depends on the nature of the rock. I have, however, seen in the Alps swallow-holes which have been modified by the erosive action of the streamlet.

The large amount of debris supposed to have existed on the surface before the Glacial Period seems to me an assumption. Many parts of the great insular mass of crystalline rock in Central France had almost certainly not boen under water from a very remote epoch, a large portion of it certainly not since Miocene times; yet there is no great amount of surface debris here, and I suppose we may dispense with an ice-sheet for Auvergne? Surely also, as soon as a layer of a few feet of debris had formed on the surface, it would greatly protect the rock beneath from all agencies but those of percolating water? Again, with regard to Mr. Goodchild's explanation of the absence of ice-marks from the higher parts of mountains (p. 360). If a glacier is an erosive agent of such power, as he supposes it to be, a very limited duration of contact with the upper rocks ought to suffice for imprinting its "handwriting on the wall." Thus, making every allowance for greater exposure to weather, we ought now and then to find the blurred remnants of these inscriptions. I have climbed more than most men in the regions of glaciers, but never saw them. To my eyes the transition from weather-worn to ice-worn rocks appears usually rather abrupt, and at a regular height.

Finally is there evidence at all that glaciers possess this immense 
erosive power? I have shown (Quart. Journ. Geol. Soc. xxvii. 312 ; xxix. 382 ; xxx. 479) that in several districts of the Alps there is evidence that the glaciers have descended important valleys, filling them almost down to the level of the present torrents, yet have been incompetent to modify their principal features, which are most characteristically those of fluviatile erosion. This argument, I venture to assert, has never been met. Exery year that I travel gives me fresh instances, and during the present summer I have met with one or two other curious facts bearing on the subject of glacier erosion, which I hope to be permitted to lay before the readers of this Magazine in a month or two.

I have thus ventured to indicate some of the reasons why Mr. Goodchild's arguments fail to convince me. If they seem rather curtly stated, I must ask him to believe it is because I am trying to discuss in a letter a subject which requires a lengthy article.

St. John's Collegr, Cambridar, Aug. 9th, 1875.

T. G. Bonney.

THE POST-PLIOCENE FORMATIONS OF THE ISLE OF MAN.

SIR,-Will you kindly allow me space for a brief rejoinder to the articles by Mr. Horne and Mr. Kinahan in the July Number of the Geological Magazine?

1. Allowing, as Mr. Horne says, that intercalated beds of sand, gravel, etc., are of common occurrence in the Lower Boulder-clay, still I cannot see that this entirely destroys the force of the argument a priori, that they would probably be of more frequent occurrence in a deposit like the Upper Boulder-clay, which was formed when the cold was less severe, and warm seasons oftener to be expected; and therefore that the highest beds in the Isle of Man, which $\mathbf{M r}$. Horne considers Lower, are, so far, more likely to be Upper Boulderclay.

2. Although it may be true that the glaciers of the post-submergence period were confined mainly to the upland valleys, and therefore that moraines might be all the memorials to he expected of them, still the sea, both before and after the second continental period, must have contained ice in sufficient quantity to produce a thick deposit of clay, such as in Lancashire, for example, is found extending from an elevation of above 1000 feet to the cliffs on the sea-coast (see Geol. Survey Map 91) ; and it was principally to marine coastice, and not to glaciers, that I attributed the Upper Boulder-clay in the Isle of Man.

3. No doubt Mr. Horne is right as to the general charaeteristics of Lower Boulder-clay in South Seotland, viz. that it is a tough clay with an abundance of ice-marked stones, without stratification, and without shells. But oven this true Lower Boulder-clay, or Till, varies according to the nature of the rocks from which it is derived, and it was with the Lower Boulder-clay as it appears in the cliffs at Blackpool, and not in Scotland, that I compared the deposits which I have taken to be such around the point of Ayre. If, however, they should prove not to be Lower Boulder-clay properly so called, nor 